\title{
Karyotype diversification in fishes of the Balistidae, Diodonti- dae and Tetraodontidae (Tetraodontiformes)
}

\author{
Sá-Gabriel Luiz Gustavo and Wagner Franco Molina* \\ Departamento de Genética e Biologia Molecular, Universidade Federal do Rio Grande do Norte, Campus Universi- \\ tário, s/n, Lagoa Nova, CEP 59078-970, Natal, RN, Brazil.
}

\begin{abstract}
Among the great marine fish diversity, the Order Tetraodontiformes is remarkable by presenting post-Perciformes modern features, representing one of the major branches of the teleosteans radiation. Patterns of chromosomal evolution in this group are not fully understood. In the present work, cytogenetical analyses were carried out in the species Balistes vetula $(2 \mathrm{n}=44 ; \mathrm{FN}=44)$ and Melichthys niger ( $2 \mathrm{n}=40$ and $\mathrm{FN}=40)$ (Balistidae), Chilomycterus antennatus $(2 \mathrm{n}=52 ; 6 \mathrm{M}+46 \mathrm{st} / \mathrm{a}, \mathrm{FN}=58)$ (Diodontidae) and Sphoeroides testudineus (2n=46; $18 \mathrm{~m}+4 \mathrm{sm}+6 \mathrm{st}+18 \mathrm{a}, \mathrm{FN}=74$ ) (Tetraodontidae), collected along the Brazilian coast and Saint Pauls Rocks. All species presented $\mathrm{Ag}$-NORs sites on a single chromosomal pair. Heterochromatic regions in this group are reduced and located at centromeric position over most of chromosomal pairs. The evolutionary patterns of chromosomal changes were diverse in the distinct Tetraodontiformes families. In Balistidae, the evolution process seems to be determined by in tandem or centric fusions, followed by pericentric inversions. The higher chromosomal number in Diodontidae indicates that centric fissions and pericentric inversions played an important role in the karyotypical definition of this group. The Tetraodontidae $S$. testudineus displayed small chromosomes with a modal number shared with other species previously analyzed from this family. Such great karyotypical diversity is compatible with a scenario of several modifications established by the adaptative irradiation of this group.
\end{abstract}

Key words: C-bands, fish cytogenetics, karyotypical diversity, pufferfish, Tetraodontiformes.

\section{INTRODUCTION}

The Tetraodontiformes order has about 428 species, distributed in nine families (Triacanthodidae, Triacanthidae, Balistidae, Monacanthidae, Ostraciidae, Triodontidae, Tetraodontidae, Diodontidae and Molidae) widely distributed circuntropically in tropical and temperate freshwater and marine environments (NELSON 1994).

Balistes vetula and Melichthys niger (Balistidae) of the Western Atlantic are outstanding because they adapt easily to artificial environments and because they are used as a food source in Northeastern Brazil (Haimovici and Klippel 2000). Furthermore, they are distributed along the coast of isolated ocean islands, forming an effective model for the detection of genetic populational patterns.

Most of the Diodontids, such as Chilomycterus antennatus, are distributed in the Atlantic, Pacific and Indian oceans, presenting characteristically

\footnotetext{
* Corresponding author: phone: +55 843211 9209; fax: +55843215 3425. e-mail: lugustavo@yahoo.com.
}

the capacity to inflate their bodies with water or air, permitting the erection of a great number of spines, if they have them. The Tetraodontids have the same geographical distribution as the other Tetraodontiformes, present toxins (tetrodoxin) in their viscera, spines on the body, and the four frontal teeth fused (SANTOS 1992). Particularly abundant on sheltered shores, such as bays and estuaries, Sphoeroides testudineus is one of the most frequent species on the Brazilian coast. These fish are considered toxic, with cases of fatal accidents caused by ingestion recorded in Bahia state (Almeida and Rocha 1989; SANTOS 1992).

This study aimed to identify the karyotypic diversity existing in the Tetraodontiformes by cytogenetic analyses carried out on B. vetula and $M$. niger (Balistidae), C. antennatus (Diodontidae) and $S$. testudineus (Tetraodontidae) using conventional staining, $\mathrm{C}$ banding, Ag-NORs and treatment with the restriction enzyme (RE) EcoRI.

\section{MATERIALS AND METHODS}

The specimens studied came from different locations, from north to south of the Brazilian coast. 
The samples consisted of four specimens of Balistes vetula from coastal reefs in Bahia (Salvador - 12 $\left.{ }^{\circ} 58^{\prime} \mathrm{S}, 38^{\circ} 31^{\prime} \mathrm{W}\right), 28$ specimens of Melichthys niger collected in Saint Pauls Rocks $\left(0^{\circ} 55^{\prime} \mathrm{N}\right.$, $29^{\circ} 21^{\prime} \mathrm{W}$ ), four individuals of Chilomycterus antennatus from Rio de Janeiro coast (Angra dos Reis - $23^{\circ} 00^{\prime} \mathrm{S}, 44^{\circ} 18^{\prime} \mathrm{W}$ and Niterói - $22^{\circ} 55^{\prime} \mathrm{S}$, $43^{\circ} 50^{\prime} \mathrm{W}$ ), and 15 specimens of Sphoeroides testudineus obtained in the Rio Grande do Norte coast (Natal - $\left.5^{\circ} 46^{\prime} \mathrm{S}, 35^{\circ} 12^{\prime} \mathrm{W}\right)$. The fishes were submitted to mitotic stimulation (LEE and ELDER 1980) for 24 hours before mitotic chromosomes were obtained by the in vitro method (GoLD et al. 1990). The Ag-NORs were detected according to the technique by Howell and BLACK (1980) and the heterochromatic segments visualization, according to SUMNER (1972).

The RE EcoRI (GAATTC), used to digest genome DNA was dissolved in buffer solution as recommended by the manufacturer (Amersham Pharmacia), at a final concentration of $0.5 \mathrm{U} / \mu \mathrm{l}$ (CAU et al. 1988). A $40 \mu \mathrm{l}$ volume was added to a previously prepared slide, covered with a slide cover and incubated in a chamber at $37^{\circ} \mathrm{C}$ for 10 hours and stained by $5 \%$ Giemsa solution for 25 minutes.

\section{RESULTS}

The diploid number observed in B. vetula was $2 \mathrm{n}=44$, acrocentrics, $\mathrm{FN}=44$ with Ag-NORs localized on the $2^{\text {nd }}$ chromosome pair in telomeric position (Figure 1 (A). M. niger showed $2 \mathrm{n}=40$, acrocentrics, $\mathrm{FN}=40$ with $\mathrm{Ag}$-NORs localized on the $5^{\text {th }}$ pair, in telomeric position. A distribution preferentially centromeric of heterochromatic regions was found in these two species (Figures 1 (B) and $2(\mathrm{~B}))$.

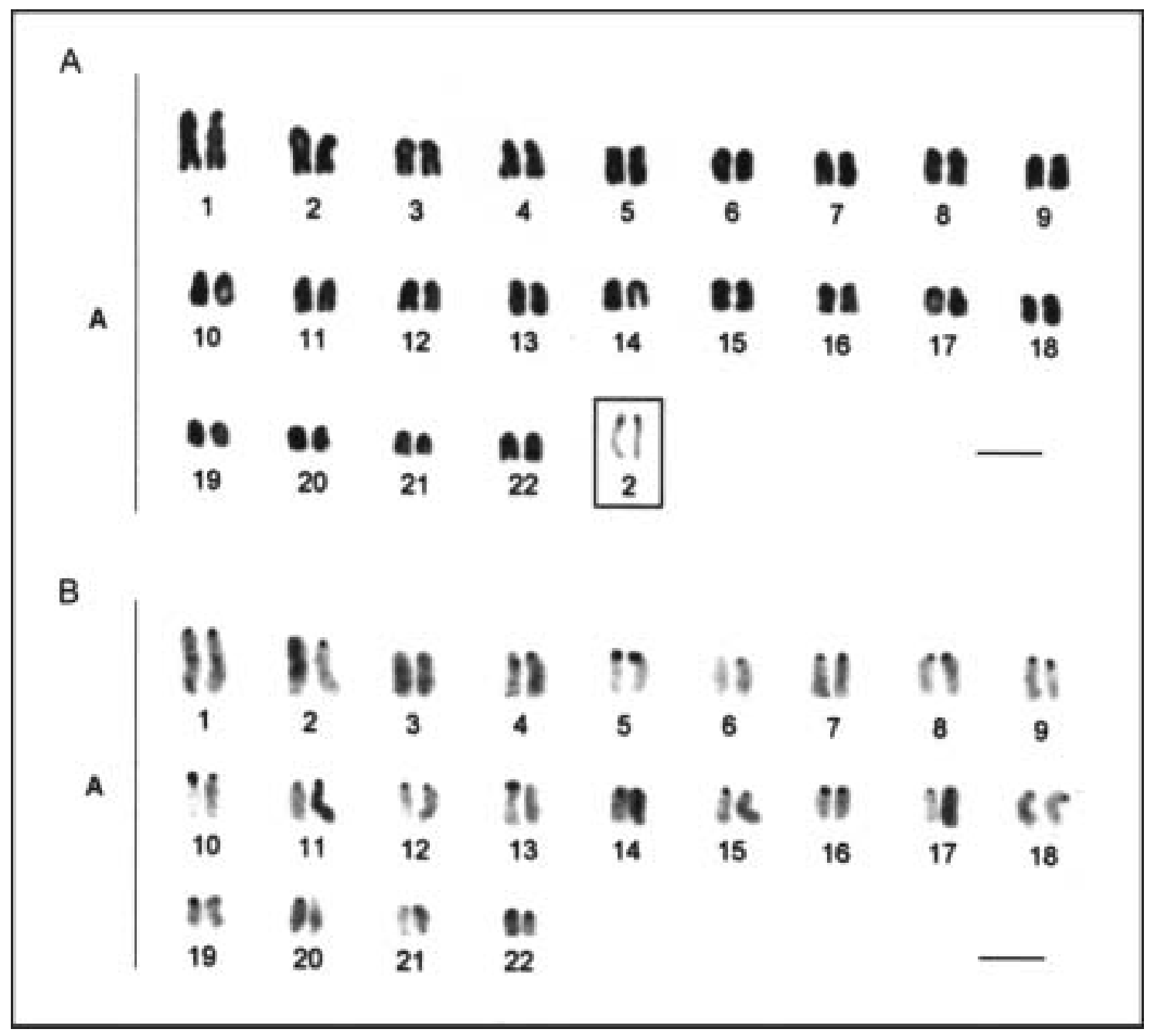

Fig. 1 - Balistes vetula karyotype. Ag-NORs sites in telomeric position on the $2^{\text {nd }}$ chromosome pair (A). C banding (B). $\mathrm{Bar}=5 \mu$. 


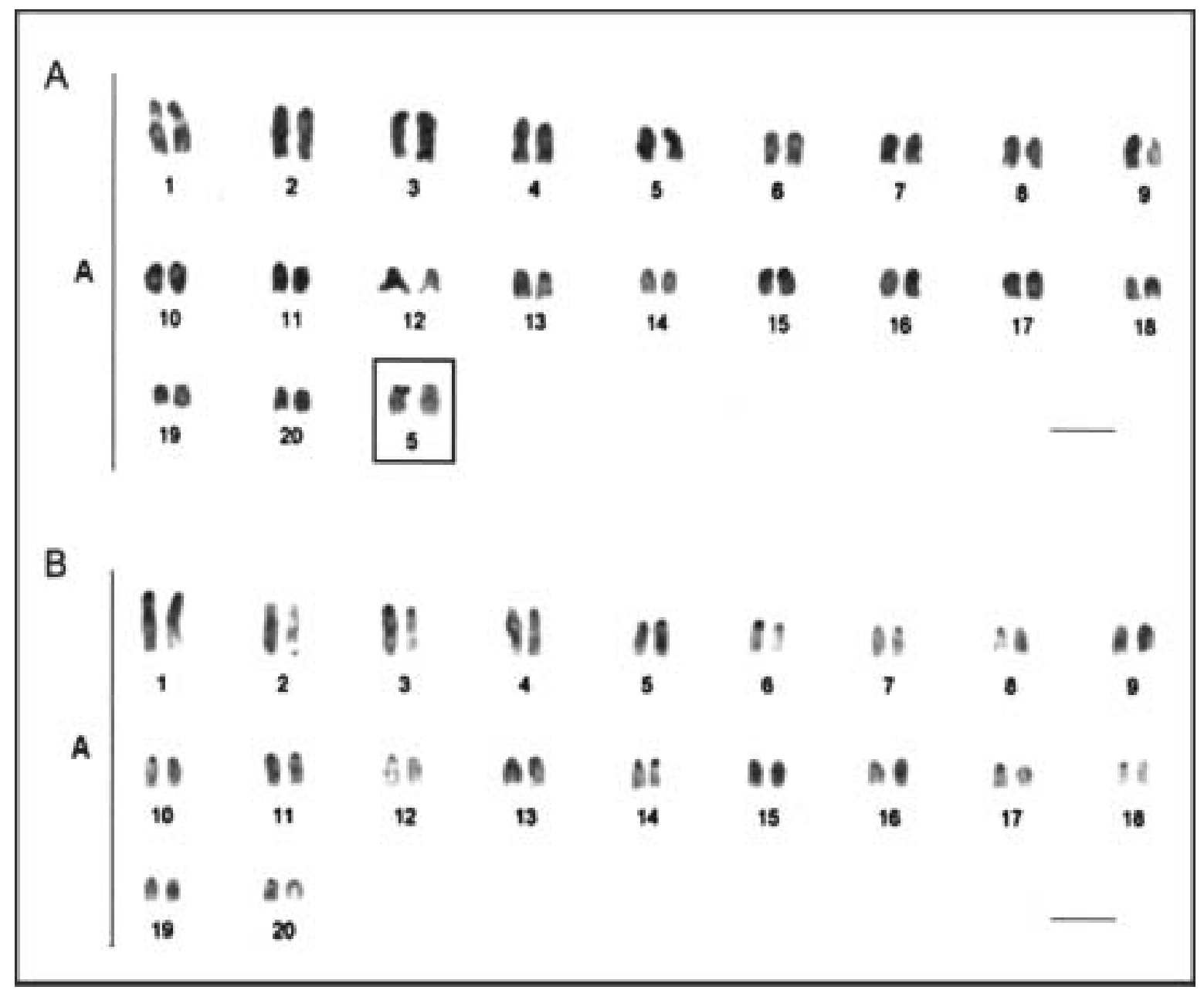

Fig. 2 - Melichthys niger karyotype with Ag-NORs localized on telomeric position of the $5^{\text {th }}$ pair, in (A). C banding (B). $\operatorname{Bar}=5 \mu$.

C. antennatus specimens showed a karyotype with $2 \mathrm{n}=52(6 \mathrm{~m}+46 \mathrm{st} / \mathrm{a}), \mathrm{FN}=58$, presenting AgNORs sites on the $2^{\text {nd }}$ pair and heterochromatic blocks distributed on most of the pairs in telomeric position (Figures $3(\mathrm{~A})$ and $(\mathrm{B})$ ).

S. testudineus showed a modal value of $2 \mathrm{n}=46$ and its karyotype consisted of diminutive sized chromosomes, with karyotypic formula equal to $18 m+4 s m+6 s t+18 a$ and $F N=74$. In this species, telomeric NORs sites were identified on the first pair of the karyotype and a heterochromatic pattern with segments distributed on the telomeric portions of its chromosomes (Figures $4 \mathrm{~A}$ and $\mathrm{B}$ ).

The treatment with RE EcoRI did not shows band patterns in the species analyzed (data not shown).

\section{DISCUSSION}

Among the Tetraodontiformes, the karyotypes of the Balistidae, Diodontidae and Tetraodon- tiformes families have been considered derived, compared to the more basal members of the Triacanthidae family (BRUM 1995).

Some previous studies on species of the Sphoeroides genus in the Atlantic (BRUM et al. 1994b; BRUM 1995) described the $S$. greeleyi $(2 \mathrm{n}=46 ; \mathrm{FN}=70)$ and $S$. spengleri $(2 \mathrm{n}=46 ; \mathrm{FN}=64)$ karyotypes from Rio de Janeiro. Another species, S. tyleri, showed a karyotype of $2 \mathrm{n}=46$, and a chromosome formula of $12 \mathrm{~m} / \mathrm{sm} /+34 \mathrm{st} / \mathrm{a} \quad(\mathrm{FN}=54)$ (BRUM 2000).

The different Tetraodontiformes families underwent an extremely diversified karyotype evolution, considering the numerical and structural aspects of their complements, with $2 \mathrm{n}$ varying from 28 to 52 chromosomes, and marked differences in the fundamental numbers that varied from 33 to 72. Analyses performed highlight the combined importance of the different chromosome rearrangements in the evolutionary modeling of their karyotypes, such as centric fissions (ARAI and NA- 


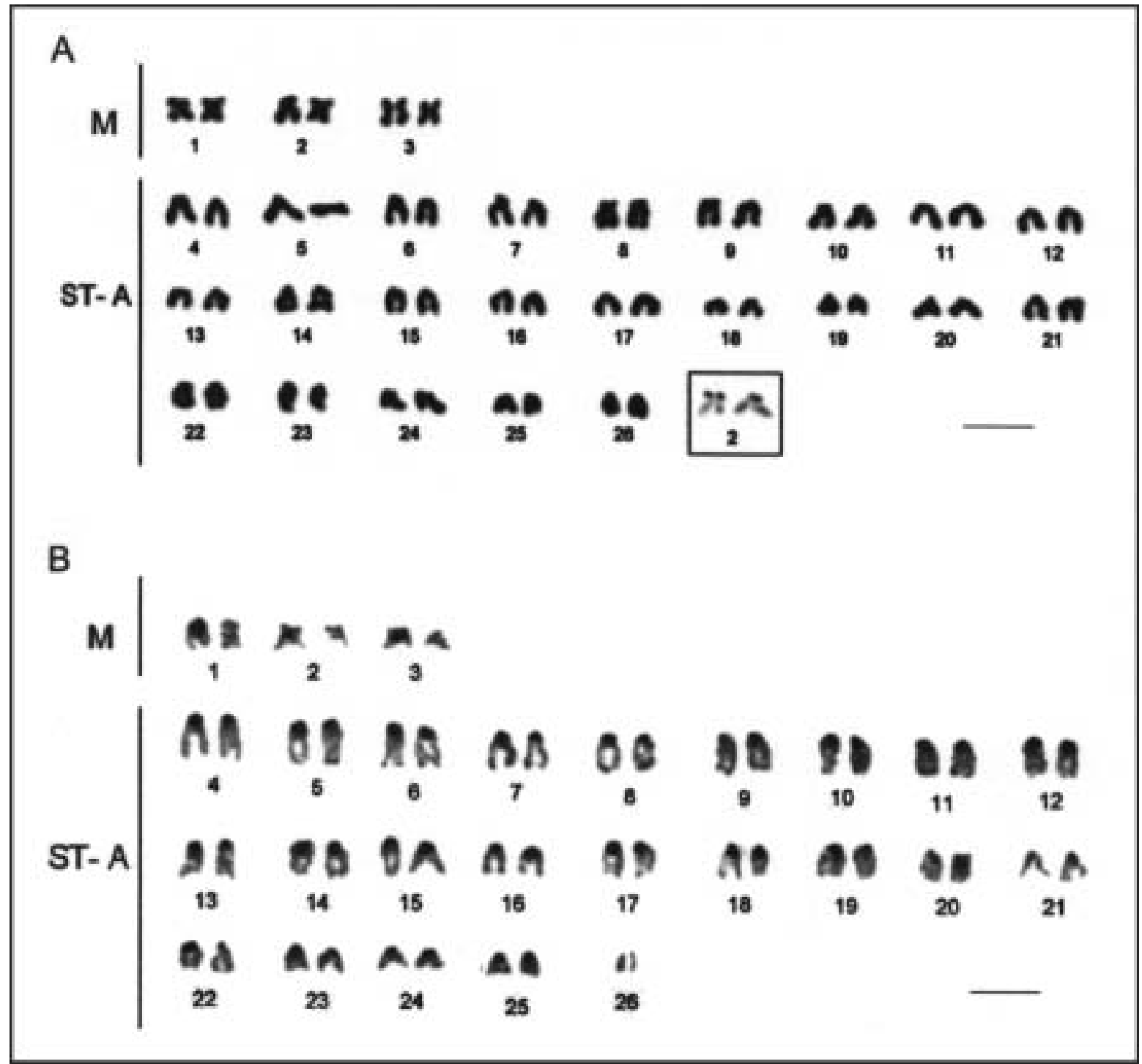

Fig. 3 - Chilomycterus antennatus karyotype. In the box the Ag-NORs site localized on the $2^{\text {nd }}$ pair (A). C banding (B). $\operatorname{Bar}=5 \mu$.

GAIWA 1976), fusion and especially pericentric inversions.

The Balistidae have diploid and FN values lower than $2 \mathrm{n}=48$, varying from 34 to 46 (MUROFUSHI and Yosida 1979; Arai and Nagaiwa 1976; TAKAI and OJIMA 1987), with most of their representatives presenting subtelo-acrocentric chromosomes. This karyotypic pattern was also observed in the present study in B. vetula $(2 \mathrm{n}=44)$ and $M$. niger $(2 \mathrm{n}=40)$. The origin of the reduced diploid numbers in these species seems to be the result of centric fusions or in tandem followed by pericentric inversions, which seems to be common in other species in the family (ARAI and NAGAIwA 1976). In the Melichthys genus a diploid value of $2 \mathrm{n}=40 \mathrm{a}$ seems to be conserved, and has been found in M. vidua (Kitayama and Ojima 1984) in addition to $M$. niger.

The Diodontidae species, Diodon bleekeri $(2 \mathrm{n}=46$ and $\mathrm{FN}=56$; ArAi and Nagaiwa 1976), $D$. bolocanthus $(2 \mathrm{n}=46, \mathrm{FN}=66$; SÁ-GABRIEL and Molina 2001) and C. spinosus $(2 \mathrm{n}=52$, with $16 \mathrm{sm}+36 \mathrm{st}$; BRUM 2000) showed a marked numerical diversity for the group. The diploid number $(2 \mathrm{n}=52)$ identified in $C$. antennatus (present study) was the largest diploid value detected for the Order up to now. It is probable that its origin has occurred by centric fission, the same evolutionary mechanism involved in species of the Ostraciidae $(2 \mathrm{n}=50)$ (ArAI and NagAIwa 1976; ArAi 1983).

The Tetraodontids, especially the Sphoeroides genus, have as karyotypic pattern the presence of 


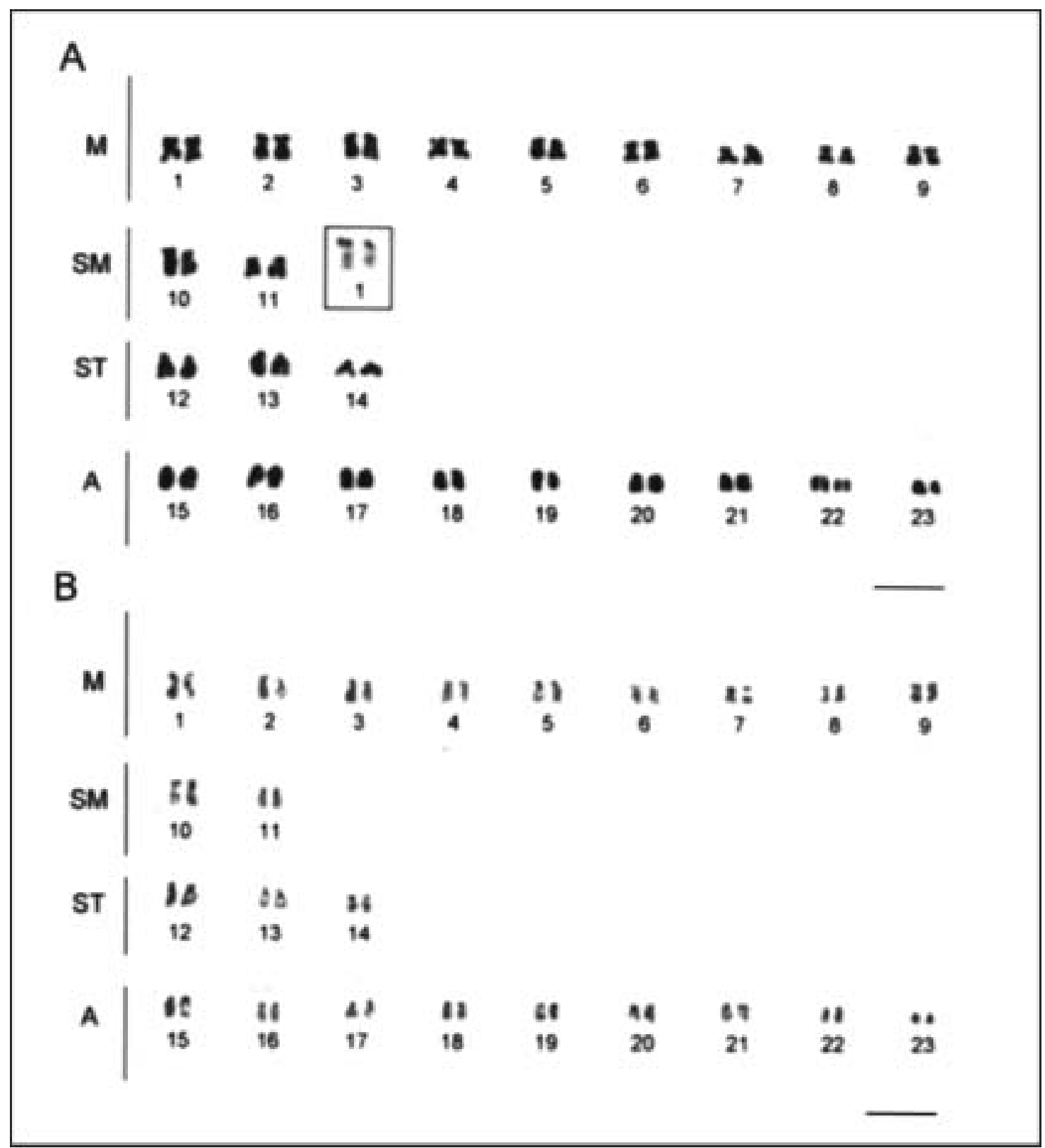

Fig. 4 - Sphoeroides testudineus karyotype. Nucleolar organizer pair ( $1^{\text {st }}$ pair) is highlighted (A). C banding (B). Bar $=5 \mu$.

small sized chromosomes, indicating its use as a model in studies of chromosome structure and functional genome aspects (BRADFORD et al. 1997; BRAINERD et al. 2001). The reduction in DNA content seems to be the peculiar mechanism involved in the Tetraodontidae genome evolution (BRAINERD et al. 2001).

Among the vertebrates, the largest and also the smallest quantities of DNA, belong to fish species. The low DNA content shown by a species is reflected in a reduced chromosome size and/or reduced chromosome number, as observed in
Tetraodon fluviatilis, the lowest DNA value known for vertebrates (LAMATSHC et al. 2000; BRAINERD et al. 2001). It is probable that differences in the genome size are connected with significant heterochromatin losses in some groups (Kloc and ZagrodZinska 2001), as may have occurred in Tetraodontidae. This is particularly evident on comparison of the karyotypes from the different families analyzed that present notable divergences for chromosome size. According to WhITE (1973), a predisposition to certain types of reorganization but not for others, such as the re- 
Table 1 - Karyotypic data disponible for Tetraodontiformes species.

\begin{tabular}{|c|c|c|c|c|c|}
\hline Famíly & Species & $2 n$ & Chromosome formula & FN & References \\
\hline \multirow{2}{*}{ TRIACANTHIDAE } & Triacanthus brevrosins & 48 & $48 \mathrm{a}$ & 48 & CHOUdHury et al., 1982 \\
\hline & T. striglifer & 48 & $48 \mathrm{a}$ & 48 & Rish, 1973 \\
\hline \multirow{20}{*}{ BALISTIDAE } & Balistapus undulatus & 42 & $42 \mathrm{st} / \mathrm{a}$ & 42 & TAKAI and OJIMA, 1987 \\
\hline & Balistes vetula & 44 & $44 a$ & 44 & SÁ-GABRIEL and Molina, 2004 \\
\hline & Balistoides conspicullum & 44 & $44 \mathrm{st} / \mathrm{a}$ & 44 & 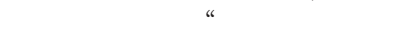 \\
\hline & B. viridescens & 44 & $2 m+2 s m+40 s t / a$ & 48 & “ \\
\hline & Cantherbines pardalis & 40 & 40 st/a & 40 & Arai and Nagaiwa, 1976 \\
\hline & Carolinensis gmelin & 44 & $44 \mathrm{a}$ & - & THode, et al., 1994 \\
\hline & Melichthys vidua & 40 & $40 \mathrm{st} / \mathrm{a}$ & 40 & Kitayama and Ojima, 1984 \\
\hline & Melichthys niger & 40 & $40 \mathrm{a}$ & 40 & SÁ-GABRIEL and Molina, 2004 \\
\hline & Novodon modestus & 40 & $40 \mathrm{st} / \mathrm{a}$ & 40 & Murofushi and Yosida, 1979 \\
\hline & Odonus niger & 42 & $42 \mathrm{st} / \mathrm{a}$ & 42 & KitAyama and Ojima, 1984 \\
\hline & Oxymonacanthus longirostris & 36 & $36 \mathrm{st} / \mathrm{a}$ & 36 & Arai and Nagaiwa, 1976 \\
\hline & Paramonacantbus japonicus & 34 & $34 \mathrm{st} / \mathrm{a}$ & 34 & Murofushi and Yosida, 1979 \\
\hline & Parika scaber & 40 & $40 \mathrm{st} / \mathrm{a}$ & 40 & Murofushi et al.,1989 \\
\hline & Pseudobalistes flavimarginatus & 44 & $2 \mathrm{sm}+42 \mathrm{st} / \mathrm{a}$ & 46 & Arai and Nagaiwa, 1976 \\
\hline & Rbineacantbus aculeatus & 44 & $44 \mathrm{st} / \mathrm{a}$ & 44 & Arai and NagAIWA, 1976 \\
\hline & R. echarpe & 44 & $44 \mathrm{st} / \mathrm{a}$ & 44 & Kitayama and Ojima, 1984 \\
\hline & R. verrucosus & 44 & $44 \mathrm{st} / \mathrm{a}$ & 44 & Arai and NagaIWA, 1976 \\
\hline & Rucanus arcodas & 36 & $36 \mathrm{st} / \mathrm{a}$ & 36 & " \\
\hline & Sufflamen chysopterus & 46 & $46 \mathrm{st} / \mathrm{a}$ & 46 & “ \\
\hline & S. traenatus & 46 & $46 \mathrm{st} / \mathrm{a}$ & 46 & TAKAI and OJIMA, 1987 \\
\hline \multirow{5}{*}{ MONACANTHIDAE } & Stephanolepis cirrbifer (M) & 33 & $30 \mathrm{st} / \mathrm{a}$ & 34 & Murofushi et al., 1980 \\
\hline & S. cirrbifer $(F)$ & 34 & $34 \mathrm{st} / \mathrm{a}$ & 34 & « \\
\hline & S. hispidus & 33 & - & - & Pauls, 1993 \\
\hline & S. hispidus (M) & 33 & $32 a+1 s m$ & 34 & SÁ-GABRIEL and Molina, 2004 \\
\hline & S. bispidus $(F)$ & 34 & $34 \mathrm{a}$ & 34 & SÁ-GABRIEL and Molina, 2004 \\
\hline \multirow{3}{*}{ OSTRACIIDAE } & Lactoria diaphana & 36 & - & 48 & ARAI, 1983 \\
\hline & Ostracion cubicus & 50 & $4 \mathrm{sm}+46 \mathrm{st} / \mathrm{a}$ & 54 & Arai and NagaIWA, 1976 \\
\hline & O. immaculatus & 50 & $4 \mathrm{sm}+46 \mathrm{st} / \mathrm{a}$ & 54 & ArAI, 1983 \\
\hline \multirow{30}{*}{ TETRAODONTIDAE } & Arotbron bispidus & 42 & $36 \mathrm{sm}+6 \mathrm{st} / \mathrm{a}$ & 78 & NATARAJAN and SubrahMANJAN, 1974 \\
\hline & A. immaculatus & 42 & $14 m+16 s m+12 s t / a$ & 72 & Arai and NagaIWA, 1976 \\
\hline & A. immaculatus & 42 & $12 \mathrm{~m}+14 \mathrm{sm}+16 \mathrm{st} / \mathrm{a}$ & 68 & CHOudHury et al.,1982 \\
\hline & A. leopardus & 40 & $14 \mathrm{~m}+14 \mathrm{sm}+12 \mathrm{st} / \mathrm{a}$ & 68 & “ \\
\hline & A. nigropunctatus & 38 & $14 m+20 s m+4 s t / a$ & 72 & Arai and Nagaiwa, 1976 \\
\hline & A. reticularis & 42 & $12 m+14 s m+16 s t / a$ & 68 & CHoudhury et al.,1982 \\
\hline & Canthigaster coronata & 28 & $8 \mathrm{~m} / \mathrm{sm}+20 \mathrm{st} / \mathrm{a}$ & 36 & ARAI, 1983 \\
\hline & C.rivulata & 34 & $4 m+6 s m+10 s t / a+14 a$ & 54 & Arai and NagAIWA, 1976 \\
\hline & Chelonodon patoca & 40 & $14 m+16 s m+10 s t / a$ & 70 & " \\
\hline & Fugu chrysops & 44 & $6 m+14 s m+24 s t / a$ & 64 & " \\
\hline & F. niphobles & 44 & $20 \mathrm{~m} / \mathrm{sm}+24 \mathrm{st} / \mathrm{a}$ & 64 & Arai and KatsuYAma, 1973 \\
\hline & F. pardalis & 44 & - & - & ARAI, 1983 \\
\hline & F. poecilonotus & 44 & - & - & ArAi, 1983 \\
\hline & Lagocephalus laevigatus & 46 & - & - & SÁ-GABRIEL and Molina, 2001 \\
\hline & L. lunaris & 44 & $10 m+14 s m+20 s t / a$ & 68 & Choudhury et al.,1982 \\
\hline & Monotetra palambangensis & 42 & - & - & HINEGARDNER and Rosen, 1972 \\
\hline & Sphoeroides greeleyi & 46 & $24 \mathrm{~m} / \mathrm{sm}+22 \mathrm{st} / \mathrm{a}$ & 70 & BRUM et al.,1994b \\
\hline & S. tyleri & 46 & $12 \mathrm{~m} / \mathrm{sm}+34 \mathrm{st} / \mathrm{a}$ & 58 & Brum et al.,1996 \\
\hline & S. spengleri & 46 & $20 \mathrm{~m} / \mathrm{sm}+26 \mathrm{st} / \mathrm{a}$ & 66 & BRUM et al.,1994b \\
\hline & S. spengleri & 46 & - & 66 & SÁ-GABRIEL and Molina, 2001 \\
\hline & S. testudineus & 46 & $18 m+4 s m+6 s t+18 a$ & 74 & SÁ-GABRIEL and Molina, 2004 \\
\hline & Takifugu niphobeles & 44 & $4 \mathrm{~m} / \mathrm{sm}+16 \mathrm{sm}+24 \mathrm{st} / \mathrm{a}$ & 64 & MIYAKI et al.,1995 \\
\hline & T. pardalis & 44 & $6 \mathrm{~m} / \mathrm{sm}+16 \mathrm{sm}+22 \mathrm{st} / \mathrm{a}$ & 66 & " \\
\hline & T. poecilonotus & 44 & $12 \mathrm{~m}+10 \mathrm{st}+22 \mathrm{st} / \mathrm{a}$ & 66 & “ \\
\hline & T. radiatus & 44 & $8 m+14 s t+22 s t / a$ & 66 & “ \\
\hline & T. rubripes & 44 & $10 m+12 s t+22 s t / a$ & 66 & “ \\
\hline & T. xanthopterus & 44 & $8 m+14 s t+22 s t / a$ & 66 & “ \\
\hline & Tetraodon cutcutia & 42 & $16 m+12 s t+10 a$ & 70 & KHUDA-BuKHSH and BARAT, 1987 \\
\hline & T. fluviatilis & 42 & $2 m+4 s m+2 s t+34 a$ & 50 & MANDRIOLI, 2000 \\
\hline & T. nigroviridis & 42 & $20 \mathrm{~m} / \mathrm{sm}+22 \mathrm{st}$ & 62 & FISHER, 2000 \\
\hline \multirow{4}{*}{ DIODONTIDAE } & Diodon bleekeri & 46 & - & 58 & Arai and NagAIWA, 1976 \\
\hline & D. bolocantbus & 46 & $20 \mathrm{~m} / \mathrm{sm}+26 \mathrm{st} / \mathrm{a}$ & 66 & SÁ-GABRIEL and Molina, 2001 \\
\hline & Chilomycterus spinosus & 52 & $16 \mathrm{~m} / \mathrm{sm}+36 \mathrm{st} / \mathrm{a}$ & 68 & BRUM, 2000 \\
\hline & C. antennatus & 52 & $6 m+46 s t / a$ & 58 & SÁ-GABRIEL and Molina, 2004 \\
\hline
\end{tabular}


duction in the DNA content, characterizes an orthoselective process. Trend for similar structural changes in the karyotype has been identified in some fish groups, such as the occurrence of Robertsonian translocation in the Chrominae subfamily (Molina and GaletTi 2002), multiple pericentric inversions in Stegastes genus (W.F. Molina, personal communication), belonging to the Pomacentridae family, or the evolution mediated by heterochromatinization events in Anostomidae (Molina et al. 1998).

Previous analyses carried out on $S$. testudineus and S. spengleri (SÁ-Gabriel and Molina 2001) indicated that this genus shows numerical conservatism, as all the species are characterized by presenting $2 n=46$ and present differentiations for the chromosome formulas, derived from pericentric inversion events. Within some genera, such as in Takifugu and Sphoeroides, were observed the occurrence of diminutive chromosomes and the presence of diversified karyotypic formulae. These characteristics group the members of this family in a condition of high specialization, not frequently observed in other fish species. Efforts to localize sex-specific sequences in this family using a great number of RAPD markers were fruitless (Li et al. 2002), corroborating the absence of sex chromosomes how shown by cytogenetic data (BRUM 1995).

All the species analyzed presented NORs sites on a single chromosome pair in telomeric position. This is considered a simplesiomorphic condition in fish (Almeida-Toledo 1985). The differences among the NOR-bearing pairs did not suggest the existence of interspecific homeology. Another peculiar cytogenetic aspect of Tetraodontiformes is the small quantity of heterochromatic regions, localized in centromeric position on most of the chromosome pairs.

The wide karyotypic diversity present in this Order is compatible with a scenario of intense changes, established by the adaptive irradiation to which the group seems to have been submitted.

The difficulty in obtaining banding patterns in fish has suggested the use of restriction endonucleases as an alternative in the study of their karyotypes. Digestion with RE has contributed to a better understanding of the chromosome structure, identifying different heterochromatin classes and chromosome polymorphisms in fish (VIÑas et al. 1998). This technique has been used in different groups of fish, such as trout and salmon (Salmoniformes, Lozano et al. 1991; Perez et al. 1999), moray (Anguilliformes, CAU et al. 1992), eels (Synbranchiformes, VIÑAs et al. 1994), cip- rinids (Cypriniformes, Padilla et al. 1993) and cartilaginous fish (Rocco et al. 1996; Rocco et al. 2002). The absence of a banding pattern after treatment with RE EcoRI was not unexpected, and can be explained by the inexistence of specific sites of action by the enzyme, as identified in Astyanax scabripinnis (MAIsTRo et al. 1999).

From the cytogenetic data obtained to these Tetraodontiformes groups it was verified that similarly to the derived morphological traits, diverse evolutionary tendencies are also reflected in their karyotypes notably diversified. This condition demonstrates an opposite tendency to the conservatism observed in Perciformes.

Acknowledgements - The authors thank CAPES for the scholarship to LGSG. The SECIRM (Secretaria da Comissão Interministerial para os Recursos do Mar), for collection facilities on the Saint Paul's Rocks.

\section{REFERENCES}

Almeida V.G. and Rocha C.M., 1989 - Registros de acidentes com peixes peçonbentos elou venenosos. Revista da Sociedade Brasileira de Toxicologia, 2: 49-51.

Almeida-Toledo L.F., 1985 - As Regiões Organizadoras do Nucléolo em Peixes. Ciência e Cultura, 37: 448-453.

Arai R. and I. Katsuyama, 1973 - Notes on the chromosomes of three species of shore-fishes. Bull. Natn. Sci. Mus. Tokio, 16: 405-409.

Arai R. and K. Nagaiwa, 1976 - Chromosomes of Tetraodontiform Fishes from Japan. Bull.Natn. Sci. Mus., 2: 59-72.

Arai R., 1983 - Karyological and osteological approach to phylogenetic systematics of tetraodontiform fishes. Bull. Natn. Sci. Mus. Tokio, 9: 175-210.

Bradford C.S., A.E. Miller, A. Tourmadje, K. Nishiyama, S. Shirahata and D. W. Barnes, 1997 Characterization of cell cultures derived from Fugu, the japanese pufferfish. Molecular Marine Biology and Biotechnology, 6: 279-288.

Brainerd E.I., S.S. Slutz, E.K. Hall and R.W. PhilLIS, 2001 - Patterns of genome size evolution in Tetraodontiform fishes. Evolution, 55: 2363-2368.

Brum M.J.I., C.C. Oliveira, M.M.O. CorrêA and P.M. Galetti Jr., 1994 - Contribuição ao conbecimento citogenético da ordem Tetraodontiformes - o cariótipo de Sphoeroides do litoral do Rio de Janeiro. V Simp. Citog. Evol. Aplic. Peixes Neotropicais, Botucatu, Brasil.

Brum, M.J.I., 1995 - Correlações entre a filogenia e a citogenética dos peixes teleósteos. Sociedade Brasileira de Genética - Série Monografias, 2: 5-42. 
Brum, M.J.I., 1996 - Cytogenetic studies of brazilian marine fish. Brazilian Journal of Genetics, 19: 421427.

BRUM, M.J.I., 2000 - Cytogenetic studies in tetraodontiforms Sphoeroides tyleri (Tetraodontiformes) and Chilomycterus spinosus (Diodontidae) from Rio de Janeiro, Brazil. Chromosome Science, 4: 103-105.

Cau, A., S. Salvadori, A.M. Deiana, J.L. Bella and R. MezzANotTe, 1988 - The characterization of $\mathrm{Mu}$ raena belena mitotic chromosomes: Karyotype, $C$-banding, nucleolar organizer regions and in situ digestion with restriction endonucleases. Cytogenetics and Cell Genetics, 47: 23-226.

Cau, A., E. Coluccia, A.M. Deiana, G. Pichiri, R. Rossino, S. Salvadori and R. Mezzanotte, 1992 - Chromosomes and DNA of Anguilla anguilla: a study with restriction endonucleases. Genome, 35: 838-843.

Choudhury, R.C., R. Prasad and C.C. Das, $1982-$ Karyological studies in five tetraodontiform fishes from the Indian Ocean. Copeia, 728-732.

FISHER, C., 2000 - Karyotype and chromosome location of characteristic tandem repeats in the pufferfish Tetraodon nigroviridis. Cytogenetics and Cell Genetics, 88: 50-55.

Gold Jr., L.C., N.S. Shipley and P.K. Powers, 1990 Improved methods for working with fish chromosomes with a review of metaphase chromosome banding. J. Fish Biol., 37: 563-575.

Haimovici, M. and S. Klippel, 2000 - Avaliação e Ações Prioritárias Para a Conservação da Biodiversidade da Zona Costeira e Marinha - Peixes Teleósteos Demersais - Diagnóstico da biodiversidade dos peixes teleósteos demersais marinhos e estuarinos do Brasil. FAT - Base de Dados Tropical.

Hinegardner, R. and Rosen D.E., 1972 - Cellular DNA content and the evolution of the teleostean fishes. Am. Nat., 106: 621-644.

Howell, W.M. and D.A. BLACK, 1980 - Controlled silver staining of nucleolus organizer region with protective colloidal developer: a 1-step method. Experientia, 36: 1014-1015.

Khuda-Bukhsh, A.R. and A. BARAt, 1987 - Chromosome in fifteen species of Indian teleosts (Pisces). Caryologia, 40: 131-144.

Kitayama, E. and Y. Ojima, 1984 - Preliminary report on the Phylogeny of five balistid fishes in terms of several chromosome banding techniques in combination with a statistical analysis. Proc. Japan. Acad., 60: 95-197.

Kloc, M. and B. ZagrodzinskA, 2001 - Chromatin elimination - an oddity or a common mechanism on differentiation and development? Differentiation, 68: 84-91.

Lamatsch, D.K., C. Steinlein, M. Schmid and M. SCHARTL, 2000 - Noninvasive determination of genome size and ploidy level in fishes by flow cytometry: detection of triploid Poecilia formosa. Cytometry, 39: 91-95.
LEE M.R. and F.F.B. ELDER 1980 - Yeast stimulation of bone marrow mitosis for cytogenetic investigations. Cytogenetic Cell Genet., 26: 36-40.

Li Y., J.A. Hill, G.H. Yue, F. Chen and L. Orban, 2002 - Extensive search does not identify genomic sex markers in Tetraodon nigroviridis. Journal of Fish Biology, 61: 1314-1317.

Lozano, R., C. Ruiz-Rejón and M. Ruiz-Rejón, 1991 - An analysis of coho salmon chromatin by means of G-bandind, Ag-and fluorochrome staining, and in situ digestion with endonucleases. Heredity 66: 403409.

Maistro, E.L., F. Foresti and C. Oliveira, $1999-R$ and G-band patterns in Astyanax scabripinnis paranae (Pisces, Characiformes, Characidae). Genetics and Molecular Biology 22: 201-204.

MANDRIOLI, M., 2000 - Cytogenetic analysis of the pufferfish Tetraodon fluviatilis (Osteichthyes). Cromosome Research 8: 237-242.

Miyaki, K., O. Tabela and H.. Kayano, 1995 Karyotype in 6 species of pufferfishes genus Takifugu (Tetraodontidae, Tetraodontiformes). Fisheries Science 61: 594-598.

Molina, W.F. and P.M. Galetti Jr., 2002 - Robertsonian rearrangements in the reef fish Chromis (Perciformes, Pomacentridae) involving chromosomes bearing $5 S$ rRNA genes. Genetics and Molecular Biology 25: 373-377.

Molina, W.F., M. Schmid and P.M. Galetti Jr., 1998 - Heterochromatin and sex chromosomes in the Neotropical fish genus Leporinus (Characiformes, Anostomidae). Cytobios 94: 141-149.

Murofushi, M. and T.H. Yosida, 1979 - Cytogenetical studies on fishes. Karyotypes of four filefishes. Jpn. J. Genet. 54: 191-195.

Murofushi, M., S. Oikawa, S. Nishikawa and T.H. YosIDA, 1980 - Cytogenetical studies on fishes. III. Multiple sex chromosomes mechanism in the filefish, Stephanolepis cirrbifer. Jpn, J Genet. 55: 127-132.

Murofushi, M., T. Nakatsubo and P.J. Smith, $1989-$ Karyological study on the New Zealand leather jacket, Perika scaber, fish of the order Tetraodontiformes. Bull. Biogeogra. Soc. Jpn. 44: 35-58.

Natarajan, R. and K. Subrahmanjan, $1974-A$ karyotype study of some teleosts forms of Portonovo waters. Proc. Ind. Acad. Sci. (B) 70: 173-16.

NeLson, J.S., 1994 - Fishes of the World. John Willey and Sons Inc., New York.

Padilla, J.A., J.L. Fernàndez-García, A. Rabasco, M. Martìnez-Trancòn, R. Ledesma and J.J. PerezREgAdERA, 1993 - Characterization of the karyotype of the tench (Tinca tinca L.) and analysis of its chromosomal heterochromatin regions by $C$-banding, Ag-staining, and restriction endonuclease banding. Cell Genet. 62: 220-223.

Pauls, E., 1993 - Estudos citogenéticos em peixes marinhos visando o melhoramento genético. Thesis. Universidade Federal Fluminense, Niterói, RJ.

Perez, J., J.L. Martinez, P. Moran, E. Beall and E. GARCIA-VAZQUEZ, 1999 - Identification of Atlantic salmon $\times$ brown trout bybrids with a nuclear marker 
useful for evolutionary studies. Journal of Fish Biology 54: 460-464.

RHISHI, K.K., 1973 - A preliminary report on the karyotypes of eighteen marine fishes. Res. Bull. (NS) of the Panjab University 24: 161-162.

Rocco, L., V. Stingo and M. BellitTi, 1996 - Cloning and characterization of a repetitive DNA detected by HindIII in the genome of Raja montagui (Batoidea, Chondrichthyes). Gene 176: 185-189.

Rocco, L., M.A. Morescalchi, D. Costagliola and V. STINGO, 2002 - Karyotype and genome characterization in four cartilaginous fishes. Gene 295: 289-298.

SÁ-Gabriel, L.G. and W.F. Molina, 2001 - Baixo conteúdo de DNA revelado pela análise citogenética de quatro espécies de baiacu (Pisces, Tetraodontiformes) do Atlântico Ocidental, Brasil. In: $47^{\circ}$ Congresso Nacional de Genética. Águas de Lindóia, SP.

SÁ-GABRIEL, L.G., 2004 — Inferências sobre a Evolução Cariotipica em Balistidae, Diodontidae, Monacanthidae e Tetraodontidae (Pisces, Tetraodontiformes). Exemplo de extensa diversificação numérica. Master's Thesis. Universidade Federal do Rio Grande do Norte, Brazil.

SANTos, E., 1992 - Nossos peixes marinhos. Zoologia Brasílica. Ed. Vila Rica, RJ.
Sumner, A.T., 1972 - A simple technique for demonstrating centromeric heterochromatin. Experimental Cell Research 75: 304.

TAKaI, A. and Y. OJIMA, 1987 - Comparative chromosomal studies in three balistid fishes. Kromosomo 47-48: 1545-1550.

Thode, G, A. Amores and G. Martinez, 1994 - The Karyotype Of Balistes: Carolinensis gmelin (Pisces, Tetraodontiformes) A Specialized Species. Caryologia, 47 (3-4): 257-263.

Viñas, A., C. Gomez, P. Martinez and L. SÀnchez, 1994 - Induction of G-bands on Anguilla anguilla chromosomes by restriction endonucleases HaeIII, HinfI and MseI. Cytogenetics and Cell Genetics 65: 79-91.

Viñas, A., C. Gomez, P. Martinez and L. SÀnchez, 1998 - Analysis of European eel (Anguilla anguilla) chromosomes after treatment with TfiI and AvaI restriction endonucleases. J. Appl. Ichthyol., 14: 113115.

White, M.J.D., 1973 - Animal Cytology and Evolution. 3rd ed. Cambridge. University Press, Cambridge.

Received 20.12.2004; accepted 7.6.2005 